\title{
Fishes from first order streams of lower Paranapanema and Ivaí rivers, upper Paraná River basin, Paraná, Brazil
}

\author{
Vivian de Mello Cionek ${ }^{1 *}$, Patricia Almeida Sacramento ${ }^{1}$, Naiara Zanatta ${ }^{1}$, Rafaela Priscila Ota ${ }^{2}$, \\ Daiany de Fatima Corbetta ${ }^{3}$ and Evanilde Benedito ${ }^{1,3,4}$ \\ 1 Universidade Estadual de Maringá, Departamento de Biologia, Pós-graduação em Ecologia de Ambientes Aquáticos Continentais. Av. Colombo \\ 5790. CEP 87020-900. Maringá, PR, Brazil. \\ 2 Instituto Nacional de Pesquisas da Amazônia, Programa de Pós-graduação em Biologia de Água Doce e Pesca Interior, Av. André Araújo 2936. CEP \\ 69060-001. Manaus, AM, Brazil. \\ 3 Universidade Estadual de Maringá, Departamento de Biologia, Pós-graduação em Biologia Comparada. Av. Colombo 5790. CEP 87020900. \\ Maringá, PR, Brazil. \\ 4 Universidade Estadual de Maringá, Núcleo de Pesquisas em Limnologia, Ictiologia e Aquicultura, Av. Colombo 5790. CEP 87020900. Maringá, PR \\ Brazil. \\ * Corresponding author. E-mail: viviancionek@gmail.com
}

\begin{abstract}
This study was developed as a research of first order streams fish assemblages located in two Conservation Units in Northwestern Paraná, Brazil, with the purpose of providing information about ichthyofauna composition of these water bodies while they are still under protection. There were captured 2,557 individuals belonging to six orders, nine families and 10 species in three streams. The most abundant species were Phalloceros harpagos (44\%) from Conceição stream, Astyanax aff. paranae (14\%) and P. harpagos (12\%) from Jurema stream, and Melanorivulus apiamici (9\%) from Conceição stream. Trichomycterus sp. could not be identified into a specific level, meaning it can represent an undescribed species to science, registered for the first time at the upper Paraná River basin.
\end{abstract}

\section{INTRODUCTION}

The upper Paraná River basin reaches more than $900,000 \mathrm{~km}^{2}$, with different habitats, including the floodplain, lagoons, canals and streams. The estimated fish richness in this system ranges up to 310 species (Langeani et al. 2007), and recent inventories have highlighted the necessity of sampling efforts in Neotropical ecosystems, due to great diversity of fishes yet to be described (Maier et al. 2008).

In particular, streams can exhibit the occurrence of high fish diversity (Casatti et al. 2001; Castro et al. 2003; 2005; Súarez 2008). These habitats are characterized by their small size, which also represents one of the major reasons they are neglect when conservation comes to matter. They must be primarily investigated, since their small size and unstable environmental conditions provides habitat for distinct fish communities, represented by small sized species. These species depend on terrestrial organic matter as food and shelter resources (Araujo and Garutti 2002) and due to their restricted mobility, may present high endemism (Castro and Menezes 1998).

According to Castro et al. (2003) small sized species represent about $50 \%$ of total freshwater fish, and in their study conducted at 17 streams from the upper Paraná River basin, 3,683 specimens, belonging to 52 species were reported. Some other researchers have registered high diversity for these ecosystems, such as 46 species from seven streams of Ivinheima River basin (Súarez 2008), 28 species from 18 streams of Sorocaba and Paranapanema River basins (Cetra et al. 2012), and 20 species of one first order stream from Ivaí River basin, under agricultural influence (Araújo et al. 2011).

Considering the importance of such water bodies to the whole basin, the ichthyofauna of three first order streams situated at different Conservation Units (Estação Ecológica do Caiuá and Parque Estadual de Amaporã) at Northwestern Paraná State were inventoried. Additionally, information about the streams is provided while they are still under protection, so they can be used as monitoring tools and knowledge source for environmental research of impacted first order streams.

\section{Materials ANd Methods}

This survey was carried out at three first order streams: Conceição (22³5'15.0"S 5253'29.0”W), Scherer

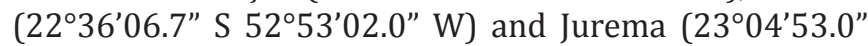
S 52 $47^{\prime} 38.3^{\prime \prime}$ W) (Figure 1). The first two streams are located at the Estação Ecológica do Caiuá, in Diamante do Norte municipality, Paraná State, and draining to the Paranapanema River sub-basin. The third is situated at the Parque Estadual de Amaporã, in Amaporã municipality, Paraná State, draining to the Ivaí River sub-basin. They all belong to the upper Paraná River basin, drain through Arenito Caiuá formation, under Floresta Estacional SemiDecidual domains, in Northwestern Paraná, Brazil (Figure 2). Sampling authorizations are: Instituto Ambiental do Paraná - no 72/2008 and Instituto Brasileiro do Meio Ambiente e dos Recursos Naturais Renováveis - no 126211.

Fishes were collected, quarterly, between June 2008 and June 2009, using electric fishing technique according to Penczak (1981) procedures, with three consecutive efforts, comprising nine sections of $40 \mathrm{~m}$ (three in each stream), with the sampling area blocked. The specimens were anesthetized using benzocaine hydrochloride and fixed in formaldehyde $10 \%$. The species were identified according 
to Graça and Pavanelli (2007), Lucinda (2008) and Costa (2011), and voucher specimens (preserved in alcohol $70 \%)$ are deposited in the Coleção Ictiológica of Núcleo de Pesquisas em Limnologia, Ictiologia e Aquicultura of Universidade Estadual de Maringá (available at http:// peixe.nupelia.uem.br) (Table 1). Fish nomenclature was according to Reis et al. (2003).

\section{RESULTS AND DISCUSSION}

A total of 2,557 specimens were collected, representing six orders, nine families and 10 species (Table 1). Species richness can be naturally low in headwater streams (Allan and Castillo 2007), due to its small size and reduced mobility presented by small fishes (Castro 1999; Braga and Andrade 2005; Agostinho et al. 2007). This could also be related to the fact that Conceição and Scherer streams discharge into Paranapanema river, right beneath Rosana reservoir and Jurema stream is dammed up, in its final

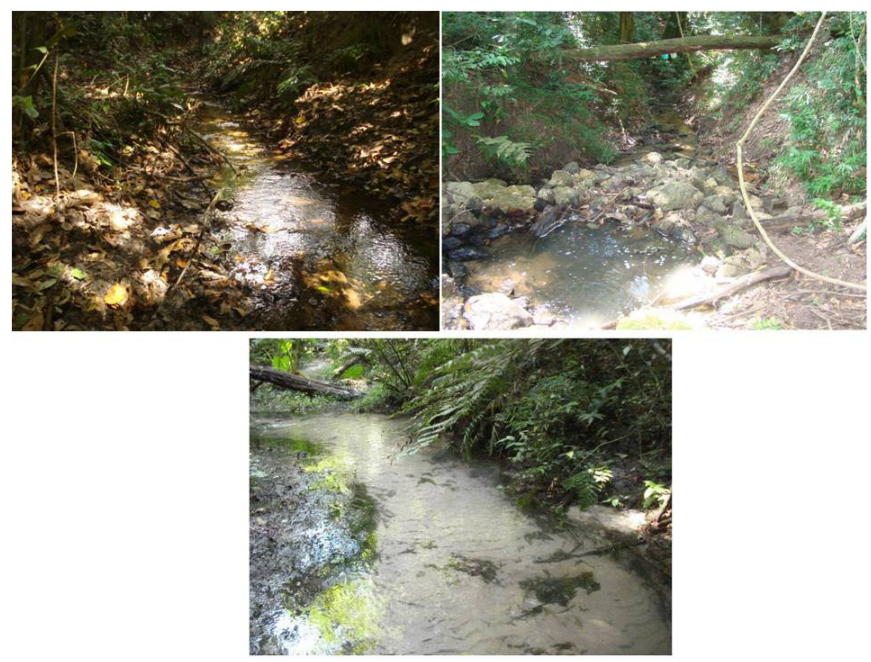

FIGURE 1. First order streams of the upper Paraná River basin. (Top-left): Conceição; (Top-right) Scherer and (Down) Jurema.

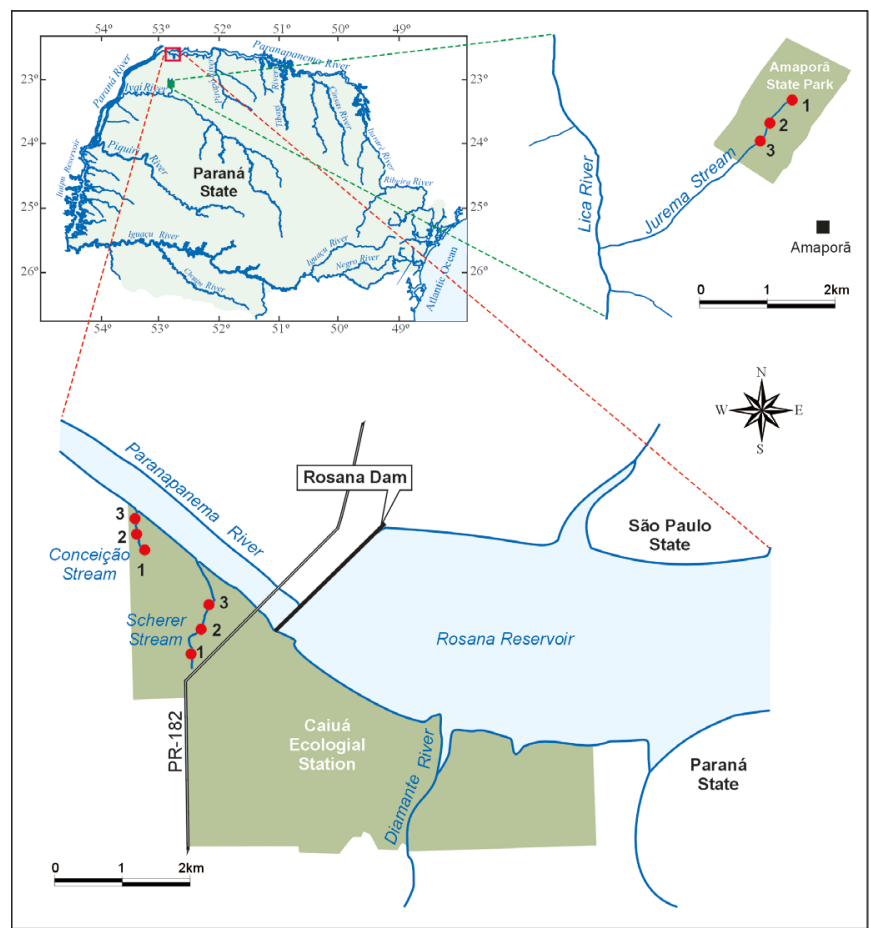

FIGURE 2. Location of the stretches sampled in Conceição and Scherer streams (Caiuá Ecological Station) and Jurema stream (Amaporã State Park). The numbers represent the sample sections in all streams. stretch, to attend the local population recreation (inside the park), which could represent barriers to small sized species dispersion.

Of all species, four were collected in Conceição stream (1,372 specimens): Phalloceros harpagos (82.6\%), Melanorivulus apiamici (17\%), Gymnotus inaequilabiatus $(0.2 \%)$ and Synbranchus marmoratus $(0.2 \%)$. In Scherer stream we also collected four species (359 specimens): Gymnotus inaequilabiatus (45.7\%), Astyanax altiparanae (44.8\%), Characidium aff. zebra (6.7\%) and Crenicichla britskii (2.8\%). Jurema stream presented five species, with a total of 826 specimens, as follows: Astyanax aff. paranae (42.8\%), P. harpagos (36.9\%), Trichomycterus sp. (18.3\%), Callichthys callichthys $(0.7 \%)$ and $G$. inaequilabiatus (0.4\%). Phalloceros harpagos occurred in both Conceição and Jurema streams, while Gymnotus inaequilabiatus occurred in Conceição and Scherer streams. Both species are characterized by their generalist behavior and ability to survive into a wide variety of environmental conditions (Campos-da-Paz, 2003; Wolff et al. 2007), favoring their presence in more than one stream.

The predominant species were represented by Characiformes, representing 30\% of captured species, followed by Siluriformes and Cyprinodontiformes (both 20\%). Gymnotiformes, Perciformes and Synbranchiformes were all represented by only one species (10\% each) (Figure 3). This pattern, with Characiformes and Siluriformes along the most species rich orders match the Neotropical pattern (Lowe-McConnell 1999). Considering all the collected species, the most abundant were Phalloceros harpagos (44\%) from Conceição, Astyanax aff. paranae $(14 \%)$ and P. harpagos $(12 \%)$ from Jurema, and Melanorivulus apiamici (9\%) from Conceição stream. The representativeness of Cyprinodontiformes appears to be a constant in first order streams, as found by Casatti (2004; 2005), Araújo et al. (2011) and Cetra et al. (2012) in streams of the upper Paraná River basin.

The high dominance of $P$. harpagos can be related to a variety of feeding habits (Casatti et al. 2009; Rocha et al. 2009) and constant reproduction (Wolff et al. 2007). This species present a preference for pools with medium water column deep and mud substrata (Mazzoni et al.2011), and in this research, groups of adult specimens were always visualized swimming, while juveniles could be seen in macrophyte banks. Melanorivulus apiamici was commonly identified as Rivulus apiamici, however, Costa (2011) in his phylogenetical study within Rivulinae, restricted the occurrence of Rivulus only to Cuba rivers, and considered Melanorivulus, previously recognized as a Rivulus subgenus, as a valid genus. It is distributed along Paraná River basin, and tends to seek for macrophytes as shelter (Bulla et al. 2011). Crenicichla britskii is geographically distributed in Southern Brazil, in the upper Paraná River basin (Kullander 2003a), and according to Casatti (2005) prefers marginal pools in association to riparian vegetation roots submerged. Astyanax aff. paranae and A. altiparanae are geographically distributed in Southern Brazil, in the upper Paraná River basin (Lima et al. 2003), present a diversified diet and can be classified as herbivorous (Rocha et al. 2009), insectivorous (Rolla et al. 2009) and omnivorous (Casatti et al. 2009), reflecting their ability to explore different microhabitats (Casatti et al. 2003). 
Some species are recognized to have similar feeding habits in different streams and usually are nominated specialists. In this study are represented by $C$. aff. zebra and Trichomycterus sp. both classified as insectivorous (Esteves and Lobón-Cerviá 2001; Esteves et al. 2008; Casatti et al. 2009). Characidium aff. zebra is distributed in the Amazon and Essequibo River basins (Buckup 2003) and their expanded fins allows the maintenance of their position and resistance to faster flowing waters, inhabiting especially rapids along the stream (Aranha et al. 2000). According to Campos-da-Paz (2003), G. inaequilabiatus is distributed especially into Paraguay River basin and lower Paraná basin, species of the genera are usually nocturnal predators with territorial behavior. The distribution of Synbranchus marmoratus covers North, Central and South America, from Mexico to Northern Argentina (Kullander 2003b). This species explores sites next to riparian vegetation (Aranha et al. 1998) and are characterized as burrowers (Kullander 2003b). Callichthys callichthys occurs in most Cis-Andean South American River drainages (Reis 2003), tend to occur in headwaters (Pavanelli and Caramaschi 2003), and according to Reis (2003) are obligatory air-breathers. These species can be classified as insectivorous, carnivorous and omnivorous, respectively (Casatti et al. 2009).

Regarding the reproductive period, the highest catch of mature individuals of all species occurred from September to December, coinciding with the period of higher temperature and rainfall. We highlight the occurrence of mature individuals of $P$. harpagos during all the sampling period, with reproductive peak between September and December (Zanatta et al. in press). According to Gomiero and Braga (2007), the same species that have prolonged reproductive period can have reproductive peaks that coincide with favorable environmental conditions to reproduction.

The studied streams are located in Conservation Units (CU), and the preserved riparian vegetation provides pristine habitats for aquatic organisms. The influence of agricultural practices that take place in the surroundings of the CU's were not notice in the nutrients concentrations (phosphorus and nitrogen), that were considered normal (pers. obs.) and matched those registered by other authors in streams from the upper Paraná River basin (Ferreira and Casatti 2006). On the other hand, the increase of runoff during rain periods around the edges and the interior of the $\mathrm{CU}$, with visual formation of ravines in the soil, along with constant visitation of students from the school close by the $\mathrm{CU}$, and the channel flow interference inflicted by anthropogenic constructions were considered the most evident influences of adjacent practices. The maintenance of quality environments depends on the monitoring of these CU's regarding visitors and the management of adjacent practices to avoid major physical impacts upon these streams, even though they still maintain preserved characteristics.

This inventory is, therefore, important because it provides valuable information about the species composition of preserved first order stream ichthyofauna. Trichomycterus sp. can represent an undescribed species to science, yet to be described for the upper Paraná River basin, which emphasizes the necessity of protection of these small streams.

TABLE 1. Fish captured in three first order streams of the upper Paraná River basin, Northwestern of Paraná, between June 2008 and June 2009. Species were classified according to Reis et al. (2003). Voucher specimens are housed at Coleção Ictiológica do Núcleo de Pesquisas em Limnologia, Ictiologia e Aquicultura, Universidade Estadual de Maringá. ${ }^{\Phi}$ Conceição stream; ‡ Jurema stream; * Scherer stream.

\begin{tabular}{|c|c|c|}
\hline CLASSIFICATION & VOUCHER & SPECIES ABUNDANCE \\
\hline \multicolumn{3}{|l|}{ CHARACIFORMES } \\
\hline \multicolumn{3}{|l|}{ Characidae } \\
\hline Astyanax altiparanae Garutti and Britski, 2000 & NUP 6068 (2 ex.) & 161 \\
\hline Astyanax aff. paranae Eigenmann, 1914 & NUP 6067 (12 ex.), 6070 (4 ex.), 6447 (3 ex.), 6451 (1 ex.) & 354 \\
\hline \multicolumn{3}{|l|}{ Crenuchidae } \\
\hline Characidium aff. zebra Eigenmann, 1909 & NUP 6071 (2 ex.) & 24 \\
\hline \multicolumn{3}{|l|}{ SILURIFORMES } \\
\hline \multicolumn{3}{|l|}{ Trichomycteridae } \\
\hline Trichomycterus sp. & NUP 6069 (3 ex.), 6449 (1 ex.) & 151 \\
\hline \multicolumn{3}{|l|}{ Callichthyidae } \\
\hline Callichthys callichthys (Linnaeus, 1758) & NUP 6122 (1 ex.) & 6 \\
\hline \multicolumn{3}{|l|}{ GYMNOTIFORMES } \\
\hline \multicolumn{3}{|l|}{ Gymnotidae } \\
\hline${ }^{\Phi *}$ Gymnotus inaequilabiatus (Valenciennes, 1839 ) & NUP 7607 (1 ex.) & $\Phi_{3} * 3$ \\
\hline \multicolumn{3}{|l|}{ CYPRINODONTIFORMES } \\
\hline \multicolumn{3}{|l|}{ Poeciliidae } \\
\hline \multirow{2}{*}{ 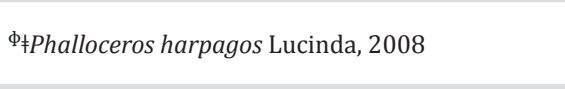 } & ${ }^{\Phi}$ NUP 6074 (3 ex.), 6463 (5 ex.), 12430 (15 ex.) & $\Phi 1133$ \\
\hline & ‡NUP 6453 (2 ex.), 6455 (2 ex.) & $\ddagger 305$ \\
\hline \multicolumn{3}{|l|}{ Rivulidae } \\
\hline Melanorivulus apiamici (Costa, 1989) & NUP 6060 (7 ex.), 6075 (3 ex.) & 233 \\
\hline \multicolumn{3}{|l|}{ PerCiformes } \\
\hline \multicolumn{3}{|l|}{ Cichlidae } \\
\hline Crenicichla britskii Kullander, 1982 & NUP 6072 (1 ex.), 7604 (1 ex.) & 10 \\
\hline \multicolumn{3}{|l|}{ SYNBRANCHIFORMES } \\
\hline \multicolumn{3}{|l|}{ Synbranchidae } \\
\hline Synbranchus marmoratus Bloch, 1795 & NUP 6073 (1 ex.), 7601 (1 ex.) & 3 \\
\hline
\end{tabular}


A

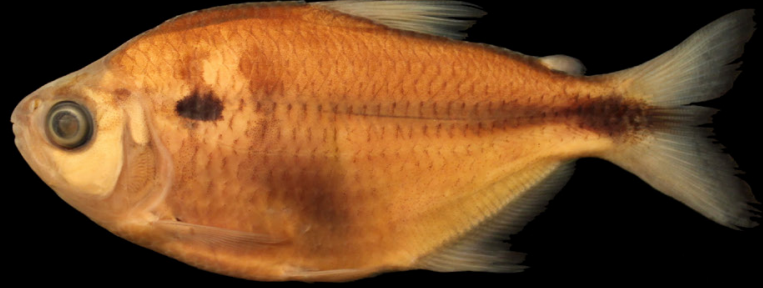

C

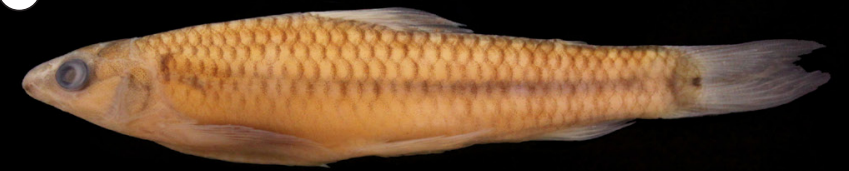

E

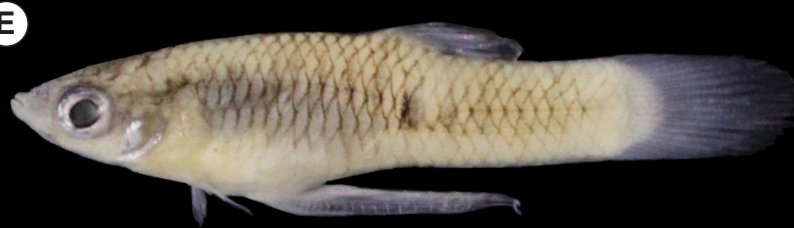

G

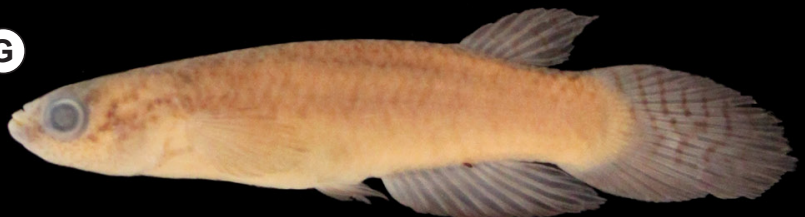

(1)

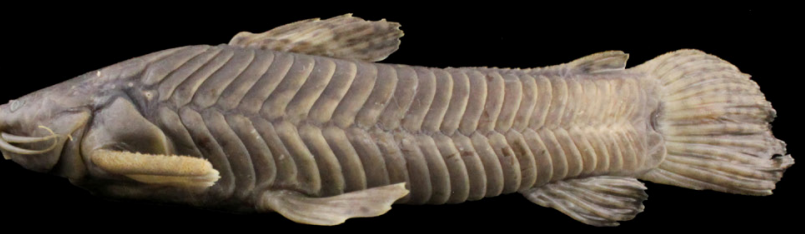

B

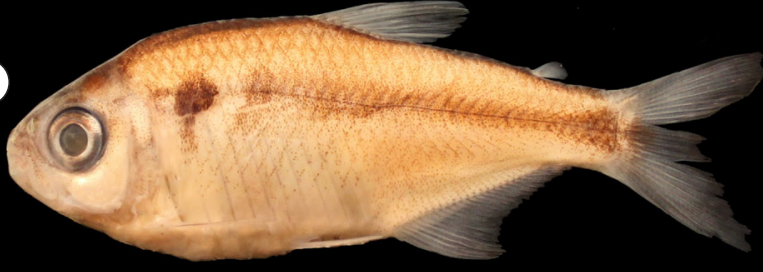

D

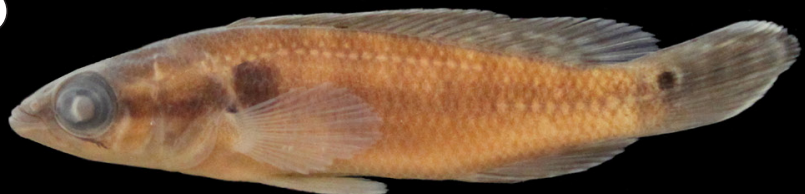

F

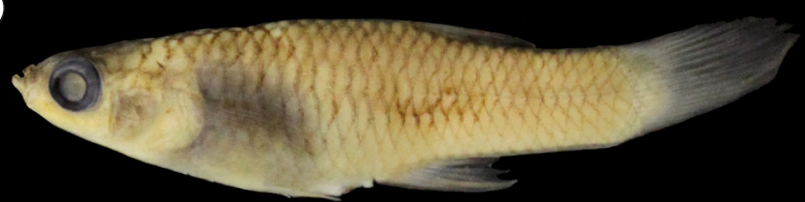

(H)

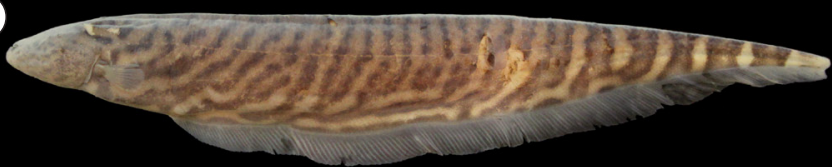

J
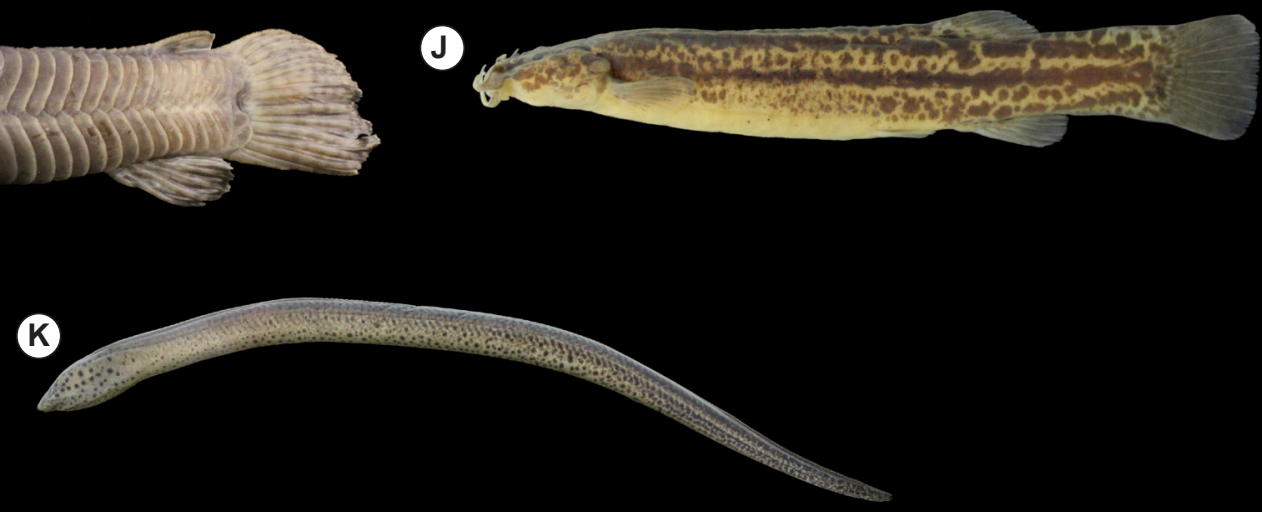

FIGURE 3. Fishes found in first order streams of the upper Paraná River basin; A) Astyanax altiparanae, NUP 7302, 61.5 mm SL, B) Astyanax aff. paranae, NUP 6451, $43.2 \mathrm{~mm} \mathrm{SL}$, C) Characidium aff. zebra, NUP 6071, $53.2 \mathrm{~mm} \mathrm{SL}$, D) Crenicichla britskii, NUP 7604, $36.7 \mathrm{~mm}$ SL, E) Phalloceros harpagos, male, NUP 12430, $20.5 \mathrm{~mm} \mathrm{SL}$, F) Phalloceros harpagos, female, NUP 6074, $28.3 \mathrm{~mm} \mathrm{SL}$, G) Melanorivulus apiamici, NUP 6060, $30 \mathrm{~mm}$ SL, H) Gymnotus inaequilabiatus, NUP 7607, $104.8 \mathrm{~mm}$ TL, I) Callichthys callichthys, NUP 6122, $71.3 \mathrm{~mm}$ SL, J) Trichomycterus sp., NUP 6069, $53.7 \mathrm{~mm}$ SL, K) Synbranchus marmoratus, NUP 13261, 182.5 mm TL. (Photographs by Luiz Fernando Tencatt).

ACKNOWLEDGMENTS: We are grateful to all who helped: Celso dos Santos, Valmir Teixeira "Gazo", José Ricardo Gonçalves "Tuti", Valdecir Casaré, Roberto Barbosa, Benedito Lopes de Castro “Mica”, José Otávio Campanha, Luciano Wolff, Ricardo Gomes, Carolina Pera, Leandro Fiori, Monica Vasques for their assistance in the field/lab work; Cláudio Zawadzki for lending the electrofishing equipment; Mário de Pinna for indentifying Trichomycterus sp., José Nelson Campanha e Doraci de Oliveira in behalf of Instituto Ambiental do Paraná (IAP) for providing accommodation and support for all the field work; CNPq for the mastership grants to the first author and productivity grants for the last author; Luiz Fernando Tencatt, Celso Ikedo and Jaime Pereira for the photographs.

\section{LITERATURE Cited}

Agostinho, A.A., F.M. Pelicice, A.C. Petry, L.C. Gomes and H.F. Júlio-Jr. 2007. Fish diversity in the Upper Paraná River basin: habitats, fisheries, management and conservation. Aquatic Ecosystems Health
Management 10(2): 174-186

Allan, J.D. and M.M. Castillo. 2007. Stream ecology: structure and function of running waters. Dordrecht: Springer. 436p.

Aranha, J.M.R. D.F Takeuti and T.M. Yoshimura. 1998. Habitat use and food partitioning of the fishes in a coastal stream of Atlantic Forest, Brazil. Revista de Biologia Tropical 46(4): 951-959.

Aranha, J.M.R., J.H. Gomes and F.N.O. Fogaca. 2000. Feeding of two sympatric species of Characidium, C. lanei and C. pterostictum (Characidiinae) in a coastal stream of Atlantic Forest (Southern Brazil). Brazilian Archives of Biology and Technology 43(5): 527-531.

Araujo, R.B. and V. Garutti. 2002. Biologia reprodutiva de Aspidoras fuscoguttatus (Siluriformes, Callichthyidae) em riacho de cabeceira da bacia do alto Rio Paraná. Iheringia: Série Zoologica 92(4): 89-98.

Araújo, M.I., R.L. Delariva, K.O. Bonato and J.C. Silva. 2011. Fishes in first order stream in Ivaí River drainage basin, upper Paraná River basin Paraná state, Brazil. Check List 7(6): 774-777. 
Braga, F.M.S. and P.M. Andrade. 2005. Distribuição de peixes na microbacia do Ribeirão Grande, Serra da Mantiqueira Oriental, São Paulo, Brasil. Iheringia: Série Zoologica 95(2): 121-126.

Buckup, P.A. 2003. Family Crenuchidae; p. 87-95 In R.E. Reis, S.0. Kullander and C.J. Ferraris Jr (ed.). Checklist of the Freshwater Fishes of South and Central America. Porto Alegre: EDIPUCRS.

Bulla, C.K., L.C. Gomes, L.E. Miranda and A.A. Agostinho. 2011. The ichthyofauna of drifiting macrophyte mats in the Ivinheima River, upper Paraná River basin, Brazil. Neotropical Ichthyology 9(2): 403409.

Campos-da-Paz, R. 2003. Family Gymnotidae; p. 483-486 In R.E. Reis, S.O. Kullander and C.J. Ferraris Jr (ed.). Checklist of the Freshwater Fishes of South and Central America. Porto Alegre: EDIPUCRS.

Casatti, L., F. Langeani and R.M.C. Castro. 2001. Peixes de riacho do Parque Estadual Morro do Diabo, bacia do Alto Rio Paraná. Biota Neotropica 1(1,2): 1-15.

Casatti, L., H.F. Mendes and K.M. Ferreira. 2003. Aquatic macrophytes as feeding site for small fishes in the Rosana Reservoir, Paranapanema River, Southeastern Brazil. Brazilian Journal of Biology 63(2): 213222.

Casatti, L. 2004. Ichthyofauna of two streams (Silted and Reference) in the Upper Paraná River Basin, Southeastern Brazil. Brazilian Journal of Biology 64(4): 757-765.

Casatti, L. 2005. Fish assemblage structure in a first order stream, southeastern Brazil: longitudinal distribution, seasonality, and microhabitat diversity. Biota Neotropica 5(1): 75-83.

Casatti, L., C.P. Ferreira and F. Langeani. 2009. A fish-based biotic integrity index for assessment of lowland streams in southeastern Brazil. Hydrobiologia 623: 173-189.

Castro, R.M.C. and N.A. Menezes. 1998. Estudo diagnóstico da diversidade de peixes do Estado de São Paulo; p. 1-13 In R.M.C. Castro (ed.). Biodiversidade do Estado de São Paulo, Brasil: Síntese do conhecimento ao final do século XX, vertebrados. São Paulo: WinnerGraph.

Castro, R.M.C. 1999. Evolução da ictiofauna de riachos sul-americanos: padrões gerais e possíveis processos causais; p. 139-155 In E.P. Caramaschi, R. Mazzoni, P.R. Peres-neto (ed.). Ecologia de Peixes de Riachos. Série Oecologia Brasiliensis. Rio de Janeiro: PPGE-UFRJ.

Castro, R.M.C., L. Casatti, H.F. Santos, K.M. Ferreira, A.C. Ribeiro, R.C. Benine, G.Z.P. Dardis, A.L.A. Melo, R. Stopoglia, T.X. Abreu, F.A Bockmann, M. Carvalho, F.Z. Gibran and F.C.T. Lima. 2003. Estrutura e Composição da ictiofauna de riachos do rio Paranapanema, Sudeste e Sul do Brasil. Biota Neotropica 3(1): 1-31.

Castro, R.M.C., L. Casatti, H.F. Santos, R.P. Vari, A.L.A. Melo, L.S.F. Martins, T.X. Abreu, R.C. Benine, F.Z. Gibran, A.C. Ribeiro, F.A. Bockmann, M. Carvalho, G.Z. Pelição, K.M. Ferreira, R. Stopglia and A. Akama. 2005. Structure and composition of the stream icthyofauna of four tributary Rivers of the upper Rio Paraná basin, Brazil. Ichthyological Exploration of Freshwaters 16(3): 193-214.

Cetra M., W. Barrella, F. Langeani Neto, A.G. Martins, B.J. Mello and R.S. Almeida. 2012. Fish fauna of headwater streams that cross the Atlantic Forest of south São Paulo state. Check List 8(3): 421-425.

Costa, W.J.E.M. 2011. Phylogenetic position and taxonomic status of Anablepsoides, Atlantirivulus, Cynodonichthys, Laimosemion and Melanorivulus (Cyprinodontiformes: Rivulidae). Ichthyological Exploration of Freshwaters 22(3): 233-249.

Esteves, K.E. and J. Lobón-Cerviá. 2001. Composition and trophic structure of a fish community of a clear water Atlantic rainforest stream in southeastern Brazil. Environmental Biology of Fishes 62: 429-440.

Esteves, K.E., A.V.P. Lobo and M.D.R. Faria. 2008. Trophic structure of a fish community along environmental gradients of a subtropical river (Paraitinga River, Upper Tietê River Basin, Brazil). Hydrobiologia 598: 373-387.

Ferreira, A.C.P. and L. Casatti. 2006. Influência da estrutura do hábitat sobre a ictiofauna de um riacho em uma micro-bacia de pastagem, São Paulo, Brasil. Revista Brasileira de Zoologia 23(3): 642-651.

Gomiero, L.M. and F.M.S. Braga. 2007. Reproduction of a fish assemblage in the state of São Paulo, southeastern Brazil. Brazilian Journal of Biology 67(2): 283-292.
Graça, W.J. and C.S. Pavanelli. 2007. Peixes da planície de inundação do alto rio Paraná e áreas adjacentes. Maringá: Editora da Universidade Estadual de Maringá. 241 p.

Kullander, S.0. 2003a. Cichlidae (Cichlids); p. 605-654 In R.E. Reis, S.0. Kullander and C.J. Ferraris Jr. (ed.). Checklist of the Freshwater Fishes of South and Central America. Porto Alegre: EDIPUCRS.

Kullander, S.0. 2003b. Family Synbranchidae; p. 594-595 In R.E. Reis, S.0. Kullander and C.J. Ferraris Jr. (ed.). Checklist of the Freshwater Fishes of South and Central America. Porto Alegre: EDIPUCRS.

Langeani, F., R.M.C. Castro, O.T. Oyakawa, O.A. Shibatta, C.S. Pavanelli and L. Casatti. 2007. Diversidade da ictiofauna do Alto Rio Paraná: composição atual e perspectivas futuras. Biota Neotropica 7(3): 181195.

Lima, F.C.T., L.R. Malabarba, P.A. Buckup, J.F.P. Silva, R.P. Vari, A. Harold, R. Benine, O.T. Oyakawa, C.S. Pavanelli, N.A. Menezes, C.A.S. Lucena, M.C.S.L. Malabarba, Z.M.S. Lucena, R.E. Reis, F. Langeani, L. Cassati, V.A. Bertaco, C. Moreira and P.H.F. Lucinda. 2003. Genera Incertae Sedis in Characidae; p. 106-169 In R.E. Reis, S.O. Kullander and C.J. Ferraris Jr. (ed.). Checklist of the Freshwater Fishes of South and Central America. Porto Alegre: EDIPUCRS.

Lowe-McConnell, R.H. 1999. Estudos Ecológicos de Comunidades de peixes tropicais. São Paulo: Editora da Universidade de São Paulo. 536 p.

Lucinda, P.H.F. 2008. Systematics and biogeography of the genus Phalloceros Eigenmann, 1907 (Cyprinodontiformes: Poeciliidae: Poeciliinae), with the description of twenty-one new species. Neotropical Ichthyology 6(2): 113-158.

Maier, A., C.H. Zawadzki, W.J. Graça and A.G. Bifi. 2008. Fish, Barra Bonita River, upper Paraná River basin, state of Paraná, Brazil. Check List 4(3): 336-340.

Mazzoni, R., V.C. Novaes and R. Iglesias-Rios. 2011. Microhabitat use by Phalloceros harpagos Lucinda (Cyprinodontiformes: Poeciliidae) from a coastal stream from Southeast Brazil. Neotropical Ichthyology $9(3):$ 665-672.

Pavanelli, C.S. and E.P. Caramaschi. 1997. Composition of the ichthyofauna of two tributaries of the Paraná River, Porto Rico, Paraná State, Brazil. Ichthyological Explorations of Freshwaters 8(1): 23-31.

Penczak, T. 1981. Ecological fish production in two small lowland Rivers in Poland. Oecologia 48: 107-111.

Reis, R.E. 2003. Family Callichthyidae; p. 291-309 In R.E. Reis, S.O. Kullander and C.J. Ferraris-Jr. (ed.). Checklist of the Freshwater Fishes of South and Central America. Porto Alegre: EDIPUCRS.

Reis, R.E., S.O. Kullander, C.J. Ferraris Jr. 2003. Check List of the Freshwater Fishes of South and Central America. Porto Alegre: EDIPUCRS. 729 p.

Rocha, F.C., L. Casatti and D.C. Pereira. 2009. Structure and feeding of a stream fish assemblage in Southeastern Brazil: evidence of low seasonal influences. Acta Limnologica Brasiliensia 21(1): 123-134.

Rolla, A.P.P.R., E.E. Katharina and A.O. Ávila-da-Silva. 2009. Feeding ecology of a stream fish assemblage in an Atlantic Forest remnant (Serra do Japi, SP, Brazil). Neotropical Ichthyology 7(1): 65-76.

Súarez, Y.R. 2008. Fish, lower Ivinhema River basin streams, state of Mato Grosso do Sul, Brazil. Check List 4(3): 226-231.

Wolff, L.L., H.R. Ericsson, D. Viana and D.Zaleski. 2007. Population structure of Phalloceros caudimaculatus (Hensel, 1868) (Cyprinodontiformes, Poeciliidae) collected in a brook in Guarapuava, PR. Brazilian Archives of Biology and Technology 50(3): 417-423.

Zanatta, N., V.M. Cionek and E. Benedito. Reproductive strategies of fish populations from three Neotropical streams. Acta Scientiarum. Biological Sciences: in press.

RECEIVED: May 2012

ACCEPTED: October 2012

Published ONLINE: November 2012

EDITORIAL RESPONSIBILITY: Sergio Maia Queiroz Lima 